\title{
Ultra-Violet Spectrophotometric Method for Estimation and Validation of Amlodipine in Bulk and Tablet Formulation
}

\begin{abstract}
In the present work an inexpensive, easy, mercurial, particular, sensible and reproducible and spectrophotometric method has been developed and validated for the estimation of amlodipine in pure drug and Marketed Tablet Formulation. Analysis was carried out at $338 \mathrm{~nm}$ for pure drug amlodipine and $355 \mathrm{~nm}$ for amlodipine marketed tablet formulation. The main purpose of the investigation was to measure that how much percentage of drug present in marketed tablet formulation for the estimation of amlodipine besylate tablet and amlodipine pure drug using methanol as a solvent, a simple method has been developed. The accuracy of the method was assessed by dues studies and was found to be in spectrum of $99.80 \%$ of amlodipine pure compound and $99.20 \%$ of amlodipine marketed tablet formulation. The LOD were found 0.132 and $0.141 \mu \mathrm{g} / \mathrm{ml}$ of amlodipine pure drug and LOQ were 0.416 and $0.427 \mu \mathrm{g} / \mathrm{ml}$ of marketed tablet respectively. The result were validated found to be fair and met the admissible criteria.
\end{abstract}

Keywords: Amlodipine; Validation; Spectroscopy; Tablet
Research Article

Volume 4 Issue 6 - 2017

Bina Gidwani, Laxmikant Patel, Anshita

Gupta and Chanchal Deep Kaur*

Shri Rawatpura Sarkar Institute of Pharmacy, India

*Corresponding author: Chanchal Deep Kaur, Associate Professor and Vice-Principal of Shri Rawatpura Sarkar Institute of Pharmacy, Kumhari, Durg (C.G.), India,

Email: dr.chanchaldeep@gmail.com;

beenagidwani@gmail.com

Received: October 31, 2016 | Published: May 31, 2017

\section{Introduction}

Validation is a process of establishing documentary evidence demonstrating that a procedure, process, or activity carried out in production or testing maintains the desired level of compliance at all stages [1]. A wide variety of procedures, processes, and activities need to be validated, the field of validation is divided into a number of subsections including the following: (Smith Alice E. et al 1996) [2].

Process validation is defined as the collection and evaluation of data, from the process design stage throughout production, which establishes scientific evidence that a process is capable of consistently delivering quality products [3]. Anti-hypertensives are a class of drugs that are used to treat hypertension (high blood pressure). Antihypertensive therapy seeks to prevent the complications of high blood pressure, such as stroke and myocardial infarction. Evidence suggests that reduction of the blood pressure by $5 \mathrm{mmHg}$ can decrease the risk of stroke by $34 \%$, of ischaemic heart disease by $21 \%$, and reduce the likelihood of dementia, heart failure, and mortality from cardiovascular disease [4]. There are many classes of anti-hypertensives, which lower blood pressure by different means. Among the most important and most widely used drugs are thiazide diuretics, calcium channel blockers, ACE inhibitors, angiotensin II receptor antagonists (ARBs), and beta blockers [5].

Calcium channel blockers are drugs used to lower blood pressure. They work by slowing the movement of calcium into the cells of the heart and blood vessel walls, which makes it easier for the heart to pump and widens blood vessels. As a result, the heart doesn't have to work as hard, and blood pressure lowers. Calcium channel blockers are prescription medications that relax blood vessels and increase the supply of blood and oxygen to the heart while also reducing the heart's workload. Examples of calcium channel blockers include Amlodipine (Norvasc), Diltiazem (Cardizem, Tiazac), Felodipine, Isradipine, Nicardipine (Cardene SR), Nifedipine (Procardia), Nisoldipine (Sular), Verapamil (Calan, Verelan, Covera-HS) etc. In the present study amlodipine and its besylate salt is used. Structures are shown in Figure $1 \& 2$.

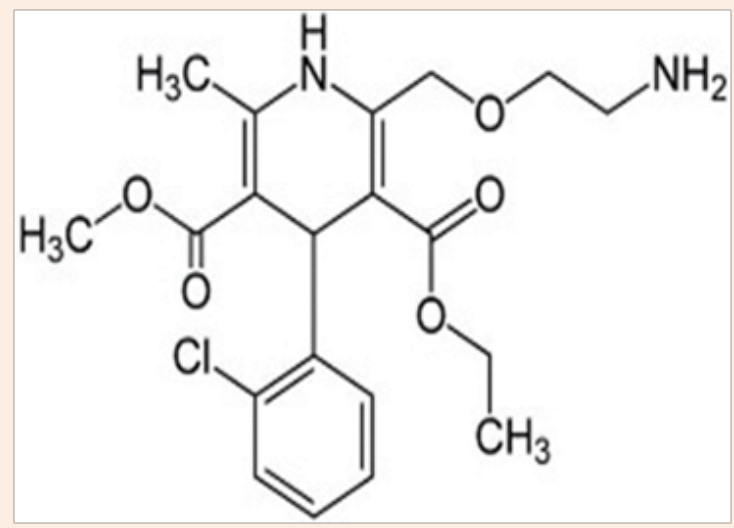

Figure 1: Chemical structure of Amlodipine. 


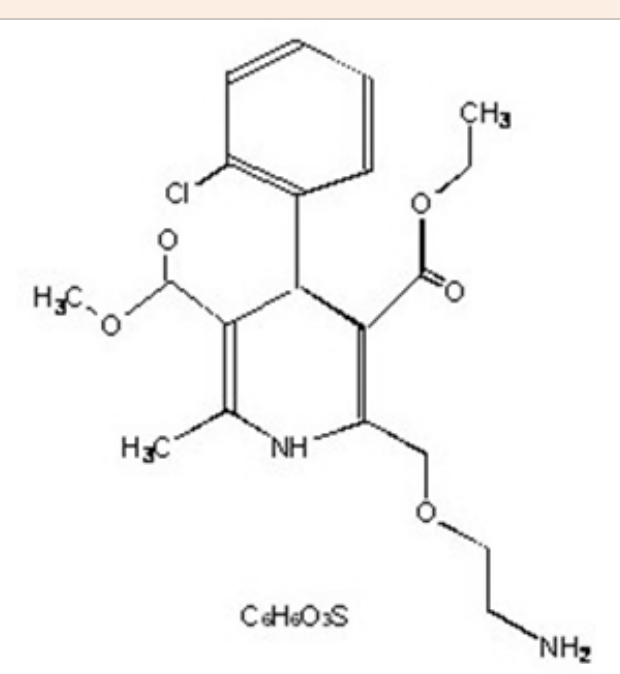

Figure 2: Chemical structure of Amlodipine Besylate.

\section{Materials}

\section{Chemicals and solvent}

Amlodipine was supplied as a gift sample by Vigor Pharmaceuticals Pvt. Ltd., Mumbai, Maharashtra (India). The

Table 1: The solubility criteria as per BP. marketed formulation tablets of amlodipine besylate 5mg Amlip Cipla Company were purchase from local market. Extra pure methanol was purchased from E. Merck Ltd, Mumbai, India. All other chemicals and solvents used for the study were of analytical grade.

\section{Apparatus}

Digital balance, FTIR instrument, double beam UV Visible spectrophotometer (1800) with resolution of $1 \mathrm{~nm} \& 0.5 \mathrm{~mm}$ slit width and a pair of $1 \mathrm{~cm}$ matched quartz cells was used to measure absorbance of the resulting solutions [6].

\section{Experimental work}

Solubility studies: In order to find an ideal solvent in which the drug amlodipine was completely soluble, solubility studies were carried out. Various solvents like distilled water, methanol, ethyl alcohol, 0.1M HCL, Chloroform, Acetic acid, Acetone etc. Firstly, for the measurement of solubility firstly $5 \mathrm{mg}$ of pure drug taken in a measuring cylinder and $1 \mathrm{ml}$ of distilled water is added, then add $2,3,5,10,30,100 \ldots$ and this procedure flowing to all organic solvents [7] (Table 1).

\section{Preparation of standard stock solution}

By dissolving $10 \mathrm{mg}$ amlodipine in $10 \mathrm{ml}$ methanol, standard solution of amlodipine was prepared. Later it was transferred into a $100 \mathrm{ml}$ volumetric flask and volume was made up to mark with methanol to make the solution of $100 \mu \mathrm{g} / \mathrm{ml}$ concentration $[8,9]$.

\begin{tabular}{|c|c|}
\hline Very Soluble & Less Than 1 Part \\
\hline Freely soluble & From 1 to 10 parts \\
\hline Soluble & From 10 to 30 parts \\
\hline Sparingly soluble & From 30 to 100 parts \\
\hline Slightly soluble & From 100 to 1000 parts \\
\hline Very slightly soluble & From 1000 to 10000 parts \\
\hline Practically soluble & More than 10000 parts \\
\hline
\end{tabular}

\section{Preparation of working standard solution}

In order to obtain working standard solution of amlodipine, prepared stock solution were further diluted with methanol. The absorbance of each solution was then measured at $338 \mathrm{~nm}$ with methanol as blank. Accurately weight $10 \mathrm{mg}$ of pure drug taken in clean dry $100 \mathrm{ml}$ of volumetric flask and dissolved in small volume of $10 \mathrm{ml}$ methanol in $100 \mathrm{ml}$ volumetric flask and volume make up into the $100 \mathrm{ml}$ up to the mark. The concentration range 10,20 , $30,40,50 \mathrm{mcg} / \mathrm{ml}$ were prepared from stock solution of pure drug than calibration curve was plotted and the correlation coefficient was calculated. Same procedure flowed for the tablet formulation. Graph was plotted by taking concentration of drug on X-axis and absorbance on Y-axis [10].

\section{Determination of maximum wavelength $\left(\boldsymbol{\lambda}_{\max }\right)$}

By scanning within range of $200-400 \mathrm{~nm}$ of a particular concentration of amlodipine solution is against a corresponding reagent blank, maximum wavelength is determined [9-11].

\section{Analysis of marketed tablet and pure drug of amlodipine}

Twenty commercial tablets were emptied and powdered. Firstly $10 \mathrm{mg}$ amlodipine powder was accurately weighed and then transferred to $10 \mathrm{~mL}$ volumetric flask and sonicated to dissolve the drug completely. Then it was filtered through $0.45 \mu$ filter and the volume is made up to $10 \mathrm{~mL}$ with methanol to get 
a concentration of $1 \mathrm{mg} / \mathrm{mL}$ stock solution. Furthermore, $1.0 \mathrm{~mL}$ of the above stock solution was pipetted into a $10 \mathrm{~mL}$ volumetric flask and diluted up to the mark to obtain required concentrations of amlodipine. The absorbance of the solution was measured at $338 \mathrm{~nm}$ bulk compound and marketed tablet $355 \mathrm{~nm}$ and amount of drug recovered was determined [9].

\section{Method validation}

As per the International Conference on Harmonization (ICH) guidelines Validation of an analytical method is done Q2 (R1) (ICH, 2005) [12]. In general, validation is defined as the process used for the confirmation of its validity i.e. the analytical procedure employed for a specific test is suitable for its intended use. Also, validation is considered as an integral part of any good analytical practice [13]. The results of method validation are used to judge the quality, trustworthy and regularity of analytical result. The USP has published specific guidelines for method validation for compound evaluation. According to USP, there are eight important parameters for validation: Accuracy, Precision, Specificity, Limit of detection, Limit of quantitation, Linearity and range, Ruggedness, Robustness [14].

\section{Accuracy}

The nearness of the test result which is obtained by the true value or reference result are expressed by the accurate analytical procedure. The recovery test or experiments for accuracy were performed by taking known amount of the drug (amlodipine) in the place. According to ICH guidelines dues studies were carried out by applying the standard addition method [15]. The experiment was performed at three different levels i.e. $80 \%, 100 \%$ and $120 \%$ of standard concentration of amlodipine. The solutions were prepared according to the above mentioned procedure and then analyzed. The percentage of recovery were calculated from the calibration curve. All the experiments were performed in triplicate [9].

\section{Precision}

Precision (repeatability) of an analytical method is a measurement of its nearness of agreement (degree of scatter) between a series of measurement by carrying out the analysis from multiple sampling of the same identical sample under the certain situation. The Intra and Inter-day precision of the marketed formulation was analyzed on the same day at different time intervals and on different days respectively. Precision of the method (intra-day precision) was estimated by carrying out six independent assays of test samples of amlodipine. The intermediate precision (inter-day precision) of the method was also determined at different days with two different analysis in the laboratory.

\section{Linearity}

Test result are obtained by analytical method in which linearity is its ability, which are directly proportional to the concentration of analyte in the sample within a given range. From this standard stock solution various concentration of the solution were prepared and the absorbance was measured. Regression equation and correlation coefficient were determined by plotting the graph between absorbance and corresponding concentration [16,17].

\section{Specificity}

Analysis of Marketed formulations (tablet of amlodipine) was done to estimate the presence of impurities, degradants and excipients in the sample and was compared with standard drug. For this the $\lambda_{\max }$ and absorbance of reference standard solution and sample solution was measured [18].

\section{Robustness and ruggedness}

The robustness of an analytical procedure is a measure of its capacity to remain unaffected by small, but deliberate variations in method parameters and provides an indication of its reliability during normal usage [12]. Robustness is evaluated during the development phase and is depended on the type of procedure used in the study. Moreover, robustness of sample shows the reliability of an analysis with respect to the variations in parameters of the method used in study. To determine the ruggedness the same procedure was carried by another analyst and the results was compared with the same previous procedure. In the present work, Robustness of the proposed method was determined by changing the $\lambda_{\max }$ of the analysis by $\pm 1.0 \mathrm{~nm}$. \% Mean recovery ( \pm $\%$ confidence interval) as well as \% relative error was reported $[19,20]$.

\section{Sensitivity and limit of detection (LOD) and limit of quantitation (LOQ)}

Sensitivity of the method was determined with respect to limit of detection (LOD) and limit of quantitation. According to ICH guidelines, the limit of detection is the lowest amount of analyte in a sample that can be detected and the limit of quantitation is the lowest amount of analyte in a sample which can be quantitatively determined with suitable precision and accuracy $[9,16]$. We have considered standard deviation of the responses and the slope for calculation of LOD and LOQ. They are expressed as under:

$$
L O D=\frac{3.3 \sigma}{S} L O Q=\frac{10 \sigma}{S}
$$
line.

Where $\sigma$ =the standard deviation of y-intercepts of regression

$$
\mathrm{S}=\text { the slope of the calibration curve. }
$$

The LOD and LOQ were determined separately through calibration curve. The residual standard deviation of a regression line or the standard deviation of y-intercepts of regression lines were used to calculate the LOD and LOQ [9].

\section{Assay}

Twenty tablets were accurately weighed and a quantity of tablet powder equivalent to $5 \mathrm{mg}$ of amlodipine besylate was weighed and then dissolved in $100 \mathrm{ml}$ methanol. The solution was then filled and further diluted to obtained final concentration of $25 \mathrm{mcg} / \mathrm{ml}$. The sample solution was analyzed and the $\%$ of drug content was determined from the absorbance using the regression equation obtained in the calibration [21]. 


\section{Results and Discussion}

\section{Solubility studies}

Determination of the solubility studies of marketed tablet formulation and vent was added \& later on in the same way solvent is increased like $2,3,4,5,10,30 \ldots . \&$ the results were determined as given in Table 2 .

Table 2: Solubility study of pure amlodipine and marketed tablet.

\begin{tabular}{|c|c|c|c|}
\hline S.no. & Solvent & $\begin{array}{c}\text { Pure Drug } \\
\text { Amlodipine }\end{array}$ & $\begin{array}{c}\text { Marketed Tablet } \\
\text { Formulation }\end{array}$ \\
\hline 1 & Distilled Water & Poor soluble & Poor soluble \\
\hline 2 & Methanol & Freely Soluble & Freely Soluble \\
\hline 3 & Ethyl alcohol & Soluble & Soluble \\
\hline 4 & 0.1 M HCL & Freely Soluble & Freely Soluble \\
\hline 5 & Chloroform & $\begin{array}{c}\text { Slightly } \\
\text { soluble }\end{array}$ & Slightly soluble \\
\hline 6 & DSMO & Freely soluble & Freely soluble \\
\hline 7 & Benzene & Poor soluble & Poor soluble \\
\hline 8 & Acetic acid & Soluble & Soluble \\
\hline
\end{tabular}

\section{Analysis of absorbance maxima pure drug amlodipine}

The absorption curve showed characteristic absorption maxima at $238 \mathrm{~nm}$ for amlodipine (pure drug). The resulting spectrum (graph between absorbance and wavelength) is shown in Figure 3.

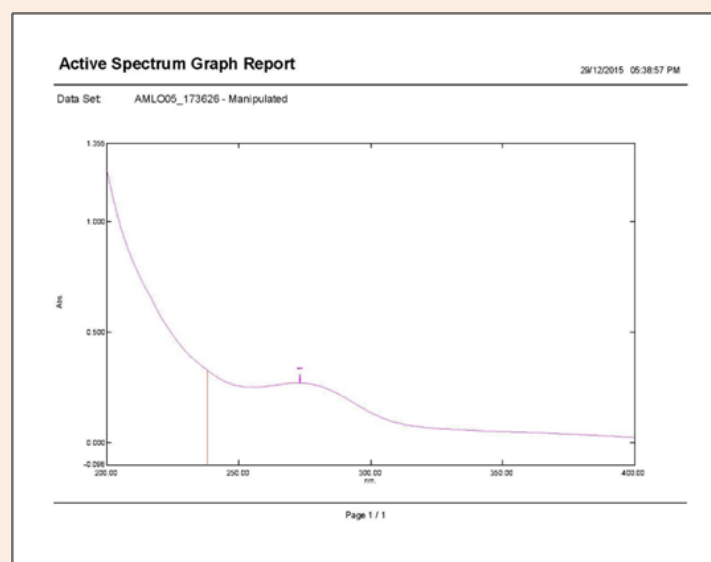

Figure 3: $\lambda$ max of amlodipine (Pure drug) by UV-spectrophotometer (Shimadzu 1800).

\section{Analysis of absorbance maxima marketed tablet formulation}

The absorption curve showed characteristic absorption maxima at $355 \mathrm{~nm}$ for amlodipine (marketed tablet formulation). The resulting spectrum (graph between absorbance \& wavelength)

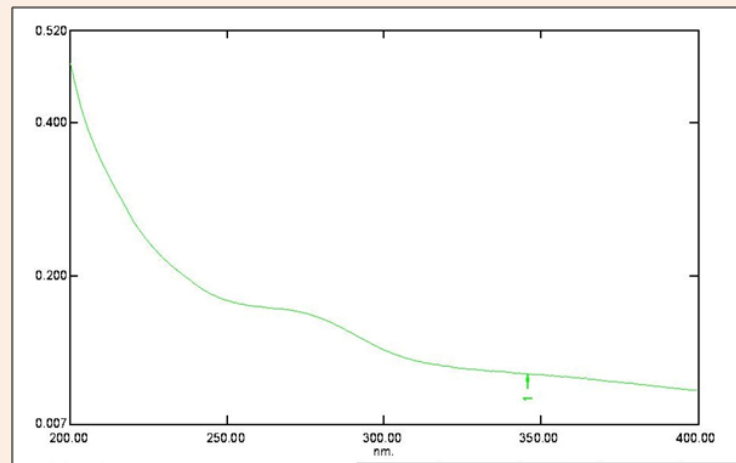

Figure 4: $\lambda \max$ of amlodipine (tablet formulation) by UVspectrophotometer (Shimadzu 1800).

is shown in Figure 4 [22-28].

\section{Preparation of calibration curve of pure drug}

The calibration curve was plotted by taking different concentration of drug on $\mathrm{x}$-axis and absorbance on y-axis and is shown in Figure 5 of pure drug amlodipine. The drug (amlodipine) obeys Beer's law in the concentration range of $10-50 \mu \mathrm{g} / \mathrm{ml}$ with coefficient of correlation $\left(R^{2}\right)=0.997$ [29-32] .

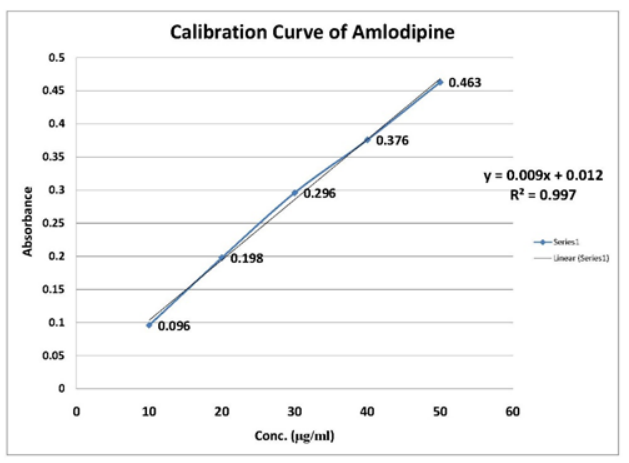

Figure 5: Calibration curve of amlodipine bulk compound.

\section{Preparation of calibration curve of marketed tablet formulation}

The calibration curve was plotted by taking different concentration of drug on $\mathrm{x}$-axis and absorbance on $\mathrm{y}$-axis and is shown in Figure 6 marketed tablet formulation. The drug (amlodipine) obeys Beer's law in the concentration range of $10-50 \mu \mathrm{g} / \mathrm{ml}$ with coefficient of correlation $\left(R^{2}\right)=0.990$. And wavelength is $355 \mathrm{~nm}[33,34]$.

\section{FTIR study of pure drug}

FTIR studies of pure amlodipine drug by using of FTIR 
instrument. The same amount of drug are used for measurement and $\mathrm{KBr}$ used as a alkali halide mixture compound. The range fixed in $4000-200 \mathrm{~nm}$. And there functional group and wavelength is determine. Results of functional groups are shown in Table 3 [35-37].

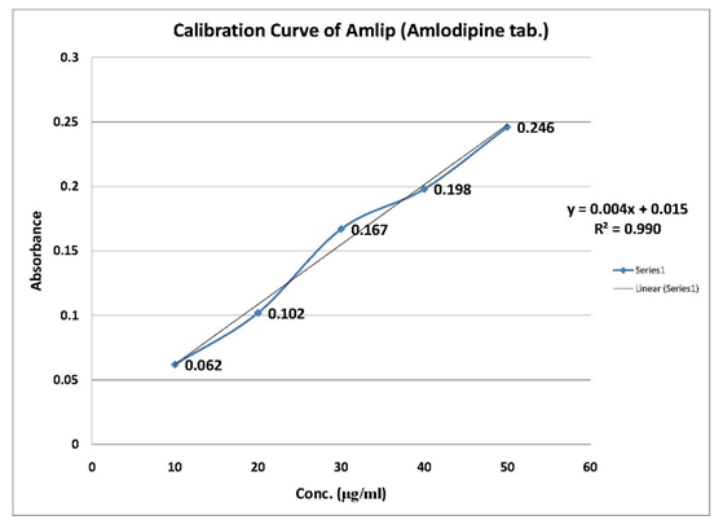

Figure 6: Calibration curve of amlodipine marketed tablet formulation.

Table 3: FTIR of pure amlodipine drug.

\section{Analysis of pure drug amlodipine and tablet formulation}

The commercially available bulk compound and marketed tablet of amlodipine were analyzed and the \% recovery of bulk drug in formulation ranged from $99.6-99.8 \%$ and formulated tablet range obtained from 98.60-98.80. The results are shown in Table 4 and 4.1. From the results it can be concluded that the \% drug content in marketed formulations is almost similar to pure drug.

\section{Accuracy of pure drug amlodipine}

The accuracy of the proposed method was estimated through recovery studies at three levels i.e. 80, 100 and 120\%. The results of the recovery studies and its statistical evaluation are summarized in Table 5 . The recovery values for amlodipine pure drug ranged from 99.12 to $99.8 \%$ [38-41].

\section{Accuracy of pure amlodipine \& marketed tablet formulation}

To determine the accuracy of the proposed method, recovery study is carried out by adding different amount $80 \%, 100 \%$, $120 \%$ of tablet formulation sample of amlodipine besylate within the linearity range and results obtained are shown in Table 5.1. The recovery values of amlodipine tablet formulation range is all most similar to the pure drug [42-45].

\begin{tabular}{|c|c|c|}
\hline S. No. & Functional group & Wavelength (nm) \\
\hline 1 & $\begin{array}{l}\text { Alkanes. a) } \mathrm{C}-\mathrm{H} \text { stretching Methyl group ( }-\mathrm{CH} 2 \text { ) } \\
\text { b) } \mathrm{C}-\mathrm{C} \text { stretching } \\
\text { c) } \mathrm{C}-\mathrm{H} \text { bending }\end{array}$ & $\begin{array}{l}3000-2840 \\
1200-1800 \\
1385-1380\end{array}$ \\
\hline 2 & $\begin{array}{l}\text { Alkenes. a) } C=C \text { unconjugated } \\
\text { b) } C=C \text { conjugated }\end{array}$ & $\begin{array}{l}1667-1640 \\
1650-1600\end{array}$ \\
\hline 3 & Alkynes. a) C - H & $700-610$ \\
\hline 4 & $\begin{array}{l}\text { Mononuclear aromatic hydrocarbons a) } \mathrm{C}-\mathrm{H} \text { bending } \\
\text { b) } \mathrm{C}-\mathrm{H} \text { stretching }\end{array}$ & $\begin{array}{l}1300-1000 \\
3100-3000\end{array}$ \\
\hline 5 & $\begin{array}{l}\text { Aldehydes. a) } \mathrm{C}=0 \text { stretching } \\
\text { b) } \mathrm{C}-\mathrm{H} \text { stretching }\end{array}$ & $\begin{array}{l}1740-1720 \\
2830-2695\end{array}$ \\
\hline 6 & Amides. a) $\mathrm{N}-\mathrm{H}$ bending & $1655-1620$ \\
\hline 7 & $\begin{array}{l}\text { Amines. a) } \mathrm{N}-\mathrm{H} \text { stretching } \\
\text { b) } \mathrm{C}-\mathrm{N} \text { stretching }\end{array}$ & $\begin{array}{l}1650-1580 \\
1250-1020\end{array}$ \\
\hline 8 & Organic halides. a) $\mathrm{C}-\mathrm{Br}$ & $690-515$ \\
\hline
\end{tabular}


Table 4: Analysis of the tablet formulation.

\begin{tabular}{|c|c|c|c|c|c|c|c|c|}
\hline Formulation & Label Claimed & \multicolumn{3}{|c|}{ Amount Recovered } & $\%$ drug & Mean & Standard & $\%$ RSD \\
\hline Amlip & $5 \mathrm{mg}$ & 4.93 & 4.95 & 4.94 & 98.6 & & & \\
\hline Amlip & $5 \mathrm{mg}$ & 4.94 & 4.94 & 4.93 & 98.8 & 4.92 & 0.0216 & 0.43906 \\
\hline Amlip & $5 \mathrm{mg}$ & 4.89 & 4.91 & 4.92 & 97.8 & & & \\
\hline
\end{tabular}

Table 4.1: Analysis of the pure drug.

\begin{tabular}{|c|c|c|c|c|c|c|c|c|}
\hline Formulation & Label Claimed & An & at $\operatorname{Rec}$ & ed & \% drug & Mean & Standard & \% RSD \\
\hline Amlodipine & $5 \mathrm{mg}$ & 4.98 & 4.97 & 4.99 & 99.6 & \multirow{3}{*}{4.98} & \multirow{3}{*}{0.00817} & \multirow{3}{*}{0.00164} \\
\hline Amlodipine & $5 \mathrm{mg}$ & 4.99 & 4.98 & 4.99 & 99.8 & & & \\
\hline Amlodipine & $5 \mathrm{mg}$ & 4.97 & 4.97 & 4.98 & 99.4 & & & \\
\hline
\end{tabular}

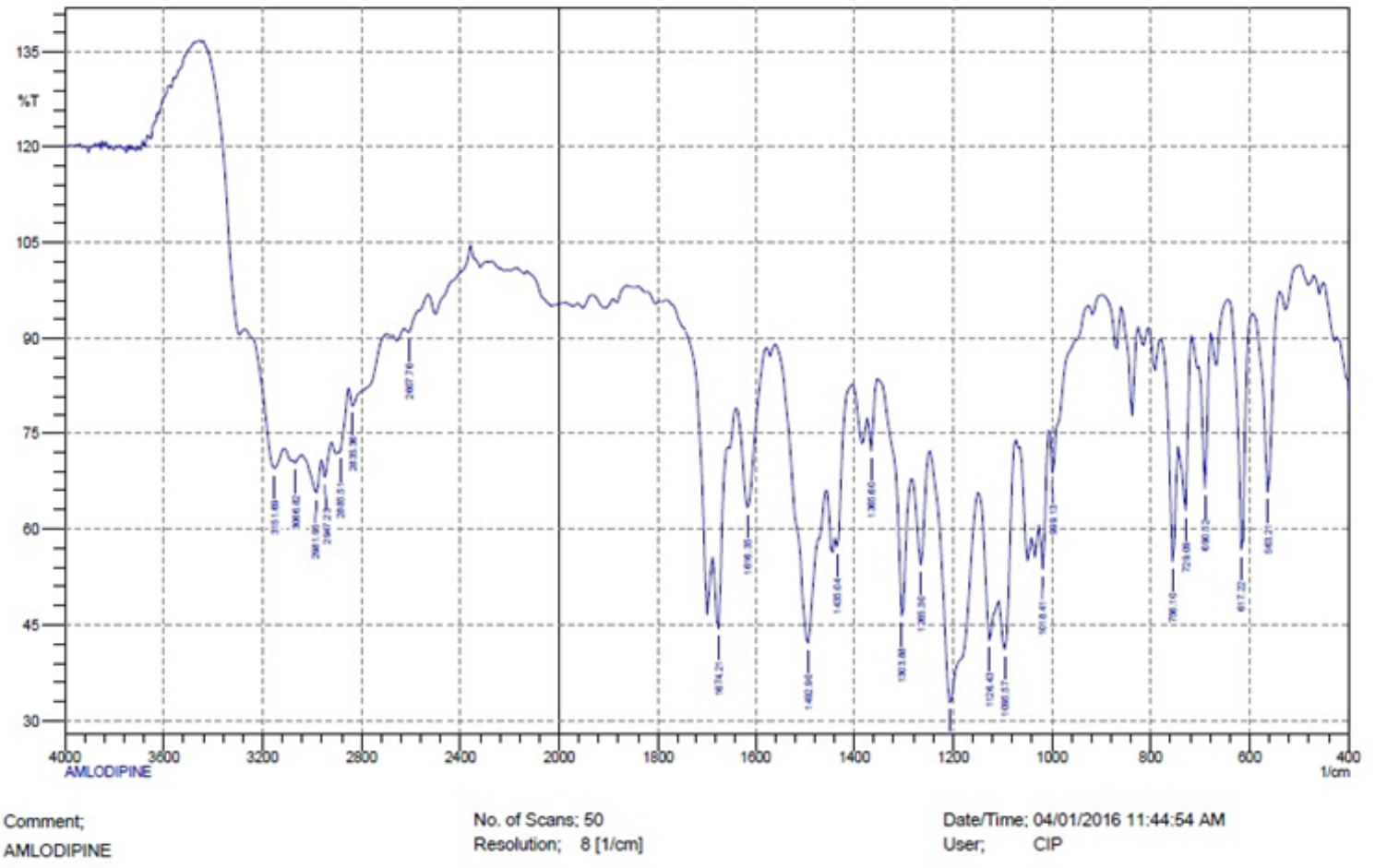

Figure 7: IR spectra of pure amlodipine compound. 
Table 5: Evaluation of accuracy study of pure drug amlodipine.

\begin{tabular}{|c|c|c|c|c|c|c|}
\hline \multirow{2}{*}{$\begin{array}{c}\text { Level of Recovery } \\
\text { (\%) }\end{array}$} & \multirow{2}{*}{$\begin{array}{l}\text { Label Claimed Amount } \\
\text { (mg) }\end{array}$} & \multirow{2}{*}{$\begin{array}{c}\text { Amount of Pure Drug } \\
\text { (mg) }\end{array}$} & \multirow{2}{*}{ \% Recovery } & \multicolumn{3}{|c|}{ Statistical Analysis } \\
\hline & & & & Mean (\%) & SD & $\%$ RSD \\
\hline 80 & 5 & 4.1 & 102.5 & \multirow{3}{*}{100.1} & \multirow{3}{*}{0.0665} & \multirow{3}{*}{0.0664} \\
\hline 80 & 5 & 3.97 & 99.25 & & & \\
\hline 80 & 5 & 3.95 & 98.75 & & & \\
\hline 100 & 5 & 4.96 & 99.02 & \multirow{3}{*}{99.07} & \multirow{3}{*}{0.01247} & \multirow{3}{*}{0.0125} \\
\hline 100 & 5 & 4.97 & 99.4 & & & \\
\hline 100 & 5 & 4.94 & 98.8 & & & \\
\hline 120 & 5 & 5.97 & 99.5 & \multirow{3}{*}{99.33} & \multirow{3}{*}{0.4714} & \multirow{3}{*}{0.00474} \\
\hline 120 & 5 & 5.96 & 99.33 & & & \\
\hline 120 & 5 & 5.96 & 99.33 & & & \\
\hline
\end{tabular}

Table 5.1: Evaluation of accuracy study of tablet formulation.

\begin{tabular}{|c|c|c|c|c|c|c|}
\hline \multirow{2}{*}{ Level of Recovery (\%) } & \multirow{2}{*}{ Label Claimed Amount (mg) } & \multirow{2}{*}{$\begin{array}{c}\text { Amount of Pure Drug } \\
\text { (mg) }\end{array}$} & \multirow{2}{*}{ \% Recovery } & \multicolumn{3}{|c|}{ Statistical Analysis } \\
\hline & & & & Mean (\%) & SD & \% RSD \\
\hline 80 & 5 & 3.96 & 99 & \multirow{3}{*}{99.08} & \multirow{3}{*}{0.007417} & \multirow{3}{*}{0.004760} \\
\hline 80 & 5 & 3.97 & 99.25 & & & \\
\hline 80 & 5 & 3.96 & 99.0 & & & \\
\hline 100 & 5 & 4.99 & 99.80 & \multirow{3}{*}{99.53} & \multirow{3}{*}{0.009428} & \multirow{3}{*}{0.009418} \\
\hline 100 & 5 & 4.97 & 99.40 & & & \\
\hline 100 & 5 & 4.97 & 99.40 & & & \\
\hline 120 & 5 & 5.98 & 99.60 & \multirow[b]{2}{*}{99.43} & \multirow[b]{2}{*}{0.008165} & \multirow[b]{2}{*}{0.008211} \\
\hline 120 & 5 & 5.96 & 99.30 & & & \\
\hline
\end{tabular}

Precision of pure drug amlodipine and tablet formulation

The developed UV-spectroscopic method found to be precise values is the \%RSD of (pure drug) values of the repeatability and intermediate precision studies were $<0.0083 \%$ and $<0.0972 \%$, respectively and tablet formulation values of the repeatability and intermediate precision studies were $<0.0291 \%$ and $<0.00479 \%$, respectively. The results of intermediate inter-day summarized in Table $6 \& 6.1$ and intra-day precision study are summarized in Table 7 \& 7.1 [46-50].

\section{Linearity of pure drug amlodipine and tablet formulation}

The linearity of the method was demonstrated over the concentration range of $10-50 \mathrm{mcg} / \mathrm{ml}$ of concentration. Accurately weight $10 \mathrm{mg}$ of pure drug taken in clean dry $100 \mathrm{ml}$ of volumetric flask and dissolved in small volume of $10 \mathrm{ml}$ methanol in $100 \mathrm{ml}$ volumetric flask and volume make up into the $100 \mathrm{ml}$ upto the mark. The concentration range $10,20,30,40,50 \mathrm{mcg} / \mathrm{ml}$ were prepared from stock solution of pure drug than calibration curve was plotted and the correlation coefficient was calculated. Same procedure flowed for the tablet formulation drug. The linearity of the response of the drug (amlodipine) was observed in concentration range from $10-50 \mu \mathrm{g} / \mathrm{ml}$ and it obeyed Beers law (Table 8) [51,52].

\section{Linearity data tablet formulation}

The linearity of the method was demonstrated over the concentration range of $10-50 \mathrm{mcg} / \mathrm{ml}$ of concentration. Accurately weight $10 \mathrm{mg}$ of tablet formulation drug taken in clean dry $100 \mathrm{ml}$ of volumetric flask and dissolved in small volume of $10 \mathrm{ml}$ methanol in $100 \mathrm{ml}$ volumetric flask and volume make up into the $100 \mathrm{ml}$ upto the mark. The concentration range $10,20,30,40$, $50 \mathrm{mcg} / \mathrm{ml}$ were prepared from stock solution of pure drug than calibration curve was plotted and the correlation coefficient was 
calculated. And calibration curve for amlodipine tablet $\mathrm{Y}=0.004 \mathrm{x}$ +0.015 . The calibration curve was found to be linear with the correlation coefficient $\left(\mathrm{R}^{2}\right)=0.990$.

\section{Specificity of pure drug amlodipine and tablet formulation}

The presence of excipients in the formulation does not interfere with the analysis of drug. Thus, the proposed method was found specific and selective for the drug. The results are shown in Table 9 of pure drug and marketed tablet formulation Table 9.1.

\section{Robustness of pure amlodipine and tablet formulation}

The evaluation data for robustness study at $10 \mu \mathrm{g} / \mathrm{ml}$ concentration is summarized in Table 10 for pure drug \& 10.1 for marketed tablet formulation.

\section{Ruggedness of pure drug amlodipine and tablet formulation}

The evaluation data for ruggedness study at $10 \mu \mathrm{g} / \mathrm{ml}$ concentration is summarized in Table 11 for pure compound \&
Table 11.1 for tablet formulation.

\section{LOD and LOQ of pure drug amlodipine and tablet formulation}

The detection limits and quantitation limits of amlodipine (Pure) were found to be 0.132 and $0.416 \mu \mathrm{g} / \mathrm{ml}$ respectively And The detection limits and quantitation limits of amlodipine (bulk) were found to be 0.141 and $0.437 \mu \mathrm{g} / \mathrm{ml}$ respectively These results prove that microgram quantity of the drug sample can also be determined accurately and precisely.

\section{Assay}

Twenty tablet were accurately weighed and a quantity of tablet powder equivalent to $5 \mathrm{mg}$ of amlodipine besylate was weighed and dissolved in $100 \mathrm{ml}$ methanol. The solution was then filled and diluted further to obtained final concentration of $25 \mathrm{mcg} / \mathrm{ml}$. The sample solution was analyzed and the \% drug content was determined from the absorbance using the regression equation obtained in the calibration. So the analyzed the marketed tablet and pure drug and resulting that the \% purity of pure and tablet formulation is similar. Results are shown in the Table 12.

Table 6: Evaluation of intraday precision study (pure drug).

\begin{tabular}{|c|c|c|c|c|c|}
\hline \multirow{2}{*}{ Time } & \multirow{2}{*}{ Amount of Drug (mg) Claimed } & \multirow{2}{*}{ Amount of Drug Recovered } & \multicolumn{3}{|c|}{ Statistical Analysis } \\
\hline & & & Mean (\%) & SD & $\%$ RSD \\
\hline \multirow{3}{*}{ Morning } & \multirow{3}{*}{$5 \mathrm{mg}$} & 4.94 & \multirow{3}{*}{98.6} & \multirow{3}{*}{ \pm 0.004714} & \multirow{3}{*}{0.00478} \\
\hline & & 4.93 & & & \\
\hline & & 4.93 & & & \\
\hline \multirow{3}{*}{ Afternoon } & \multirow{3}{*}{$5 \mathrm{mg}$} & 4.91 & \multirow{3}{*}{98} & \multirow{3}{*}{ \pm 0.008165} & \multirow{3}{*}{0.00832} \\
\hline & & 4.89 & & & \\
\hline & & 4.9 & & & \\
\hline \multirow{3}{*}{ Evening } & \multirow{3}{*}{$5 \mathrm{mg}$} & 4.89 & \multirow{3}{*}{97.6} & \multirow{3}{*}{ \pm 0.004714} & \multirow{3}{*}{0.00482} \\
\hline & & 4.88 & & & \\
\hline & & 4.88 & & & \\
\hline
\end{tabular}

Table 6.1: Evaluation of intraday precision study (tablet formulation).

\begin{tabular}{|c|c|c|c|c|c|}
\hline \multirow{2}{*}{ Time } & \multirow{2}{*}{ Amount of Drug (mg) Claimed } & \multirow{2}{*}{ Amount of Drug Recovered } & \multicolumn{3}{|c|}{ Statistical Analysis } \\
\hline & & & Mean (\%) & SD & $\%$ RSD \\
\hline \multirow{3}{*}{ Morning } & \multirow{3}{*}{$5 \mathrm{mg}$} & 4.79 & \multirow{3}{*}{93.2} & \multirow{3}{*}{ \pm 0.094163} & \multirow{3}{*}{0.10103} \\
\hline & & 4.62 & & & \\
\hline & & 4.57 & & & \\
\hline \multirow{3}{*}{ Afternoon } & \multirow{3}{*}{$5 \mathrm{mg}$} & 4.73 & \multirow{3}{*}{92.466} & \multirow{3}{*}{ \pm 0.0899} & \multirow{3}{*}{0.09722} \\
\hline & & 4.51 & & & \\
\hline & & 4.63 & & & \\
\hline \multirow{3}{*}{ Evening } & \multirow{3}{*}{$5 \mathrm{mg}$} & 4.59 & \multirow{3}{*}{88.333} & \multirow{3}{*}{ \pm 0.13888} & \multirow{3}{*}{0.15722} \\
\hline & & 4.25 & & & \\
\hline & & 4.41 & & & \\
\hline
\end{tabular}


Table 7: Evaluation of inter-day precision study of pure drug.

\begin{tabular}{|c|c|c|c|c|c|}
\hline \multirow{2}{*}{ Day } & \multirow{2}{*}{ Amount of Drug (mg) Claimed } & \multirow{2}{*}{ Mean Amount of Drug Recovered } & \multicolumn{3}{|c|}{ Statistical Analysis* } \\
\hline & & & Mean (\%) & SD & $\%$ RSD \\
\hline Day 1 & $5 \mathrm{mg}$ & 4.69 & 93.8 & \pm 0.0301 & 0.032 \\
\hline Day 2 & $5 \mathrm{mg}$ & 4.56 & 91.2 & \pm 0.0296 & 0.0291 \\
\hline Day 3 & $5 \mathrm{mg}$ & 4.44 & 88.8 & \pm 0.281 & 0.0301 \\
\hline
\end{tabular}

${ }^{*} \mathrm{n}=3$ (average of 3 determinations).

Table 7.1: Evaluation of inter-day precision study of tablet formulation.

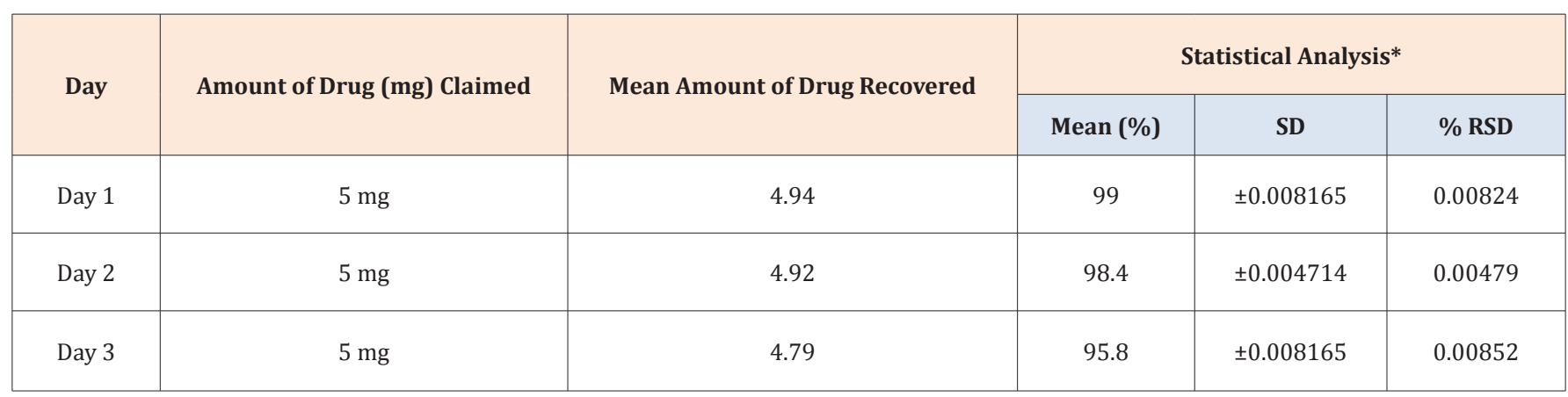

Table 8: Linearity data pure drug amlodipine.

\begin{tabular}{|c|c|}
\hline Concentration $(\boldsymbol{\mu g} / \mathbf{m l})$ & Mean Absorbance $(\mathbf{\pm S D})$ \\
\hline 0 & 0 \\
\hline 10 & 0.096 \\
\hline 20 & 0.198 \\
\hline 30 & 0.296 \\
\hline 40 & 0.376 \\
\hline 50 & 0.463 \\
\hline
\end{tabular}

The equation of the calibration curve for amlodipine pure compound was $Y=0.009 x+0.012$, the calibration curve was found to be linear with the correlation coefficient (R2) $=0.997$.

Table 9: Specificity study of pure drug
Table 8.1: Linearity data tablet formulation.

\begin{tabular}{|c|c|}
\hline Concentration $(\mu \mathrm{g} / \mathrm{ml})$ & Mean Absorbance $( \pm \mathrm{SD})$ \\
\hline 0 & 0 \\
\hline 10 & 0.062 \\
\hline 20 & 0.102 \\
\hline 30 & 0.167 \\
\hline 40 & 0.198 \\
\hline 50 & 0.246 \\
\hline
\end{tabular}

\begin{tabular}{|c|c|c|c|c|c|c|}
\hline Sr. No & Drug Amount Claimed (mg) & Amount of Drug Recovered & \% Drug Recovered & Mean & SD & \%RSD \\
\hline 1 & 5 & 4.98 & 99.6 & \multirow{3}{*}{99.73} & \multirow{3}{*}{ \pm 0.004714} & \multirow{3}{*}{0.004726} \\
\hline 2 & 5 & 4.99 & 99.8 & & & \\
\hline 3 & 5 & 4.99 & 99.8 & & & \\
\hline
\end{tabular}

Table 9.1: Specificity study of marketed tablet formulation.

\begin{tabular}{|c|c|c|c|c|c|c|c|}
\hline Sr. No & \% Excipient & Drug Amount Claimed (mg) & Amount of Drug Recovered & \% Drug Recovered & Mean & SD & $\%$ RSD \\
\hline 1 & 5 & 5 & 4.89 & 97.8 & & & \\
\hline 2 & 10 & 5 & 4.75 & 95.01 & 95.27 & \pm 0.09843 & 0.10331 \\
\hline 3 & 15 & 5 & 4.65 & 93 & & & \\
\hline
\end{tabular}


Table 10: Evaluation data of Robustness study pure drug.

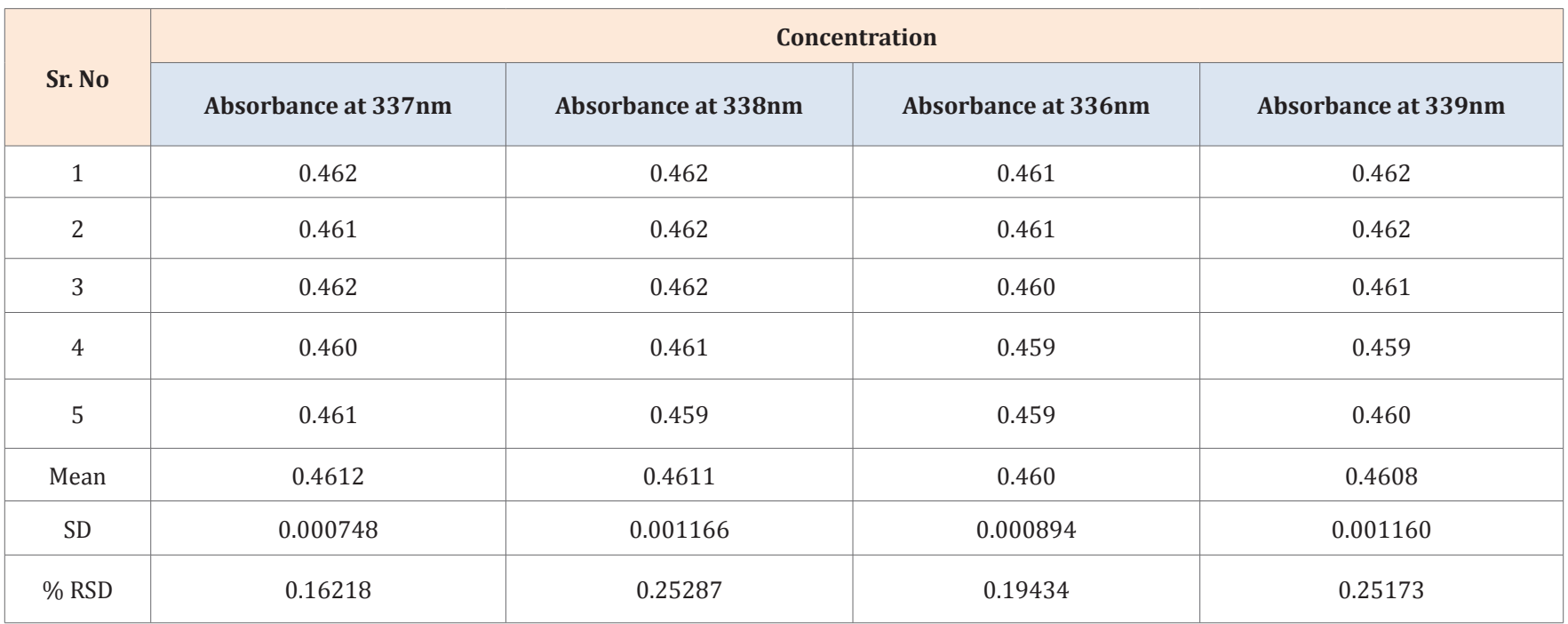

Table 10.1: Evaluation data of Robustness study tablet formulation.

\begin{tabular}{|c|c|c|c|c|}
\hline \multirow{2}{*}{ Sr. No } & \multicolumn{4}{|c|}{ Concentration } \\
\hline & Absorbance at $355 \mathrm{~nm}$ & Absorbance at $356 \mathrm{~nm}$ & Absorbance at $354 \mathrm{~nm}$ & Absorbance at $357 \mathrm{~nm}$ \\
\hline 1 & 0.371 & 0.371 & 0.370 & 0.371 \\
\hline 2 & 0.370 & 0.369 & 0.369 & 0.371 \\
\hline 3 & 0.371 & 0.369 & 0.368 & 0.370 \\
\hline 4 & 0.369 & 0.368 & 0.368 & 0.369 \\
\hline 5 & 0.369 & 0.368 & 0.367 & 0.370 \\
\hline Mean & 0.370 & 0.3693 & 0.3684 & 0.3701 \\
\hline SD & 0.000894 & 0.001095 & 0.00102 & 0.000894 \\
\hline$\%$ RSD & 0.24162 & 0.2964 & 0.27687 & 0.24162 \\
\hline
\end{tabular}

Table 11: Ruggedness study of pure drug.

\begin{tabular}{|c|c|}
\hline \multirow{2}{*}{ Concentration } & Absorbance at 338nm \\
\cline { 2 - 2 } & Analyst 1 \\
\hline $10 \mu \mathrm{g} / \mathrm{ml}$ & 0.458 \\
\hline $10 \mu \mathrm{g} / \mathrm{ml}$ & 0.458 \\
\hline $10 \mu \mathrm{g} / \mathrm{ml}$ & 0.457 \\
\hline $10 \mu \mathrm{g} / \mathrm{ml}$ & 0.456 \\
\hline $10 \mu \mathrm{g} / \mathrm{ml}$ & 0.456 \\
\hline $\mathrm{Mean}$ & 0.4570 \\
\hline $\mathrm{SD}$ & 0.000849 \\
\hline$\% \mathrm{RSD}$ & 018577 \\
\hline
\end{tabular}

Table 11.1: Ruggedness study of marketed tablet formulation.

\begin{tabular}{|c|c|}
\hline \multirow{2}{*}{ Concentration } & Absorbance at 355nm \\
\cline { 2 - 2 } & Analyst 1 \\
\hline $10 \mu \mathrm{g} / \mathrm{ml}$ & 0.365 \\
\hline $10 \mu \mathrm{g} / \mathrm{ml}$ & 0.365 \\
\hline $10 \mu \mathrm{g} / \mathrm{ml}$ & 0.363 \\
\hline $10 \mu \mathrm{g} / \mathrm{ml}$ & 0.363 \\
\hline $10 \mu \mathrm{g} / \mathrm{ml}$ & 0.362 \\
\hline $\mathrm{Mean}$ & 0.3636 \\
\hline $\mathrm{SD}$ & 0.0012 \\
\hline$\% \mathrm{RSD}$ & 0.33003 \\
\hline
\end{tabular}


Table 12: Assay of marketed tablet formulation.

\begin{tabular}{|c|c|c|c|}
\hline Drug & Label claim (mg/tab) & Amount estimated (mg/tab) & $\%$ purity \\
\hline \multirow{3}{*}{ Amlodipine pure drug } & \multirow{3}{*}{$5 \mathrm{mg}$} & 4.99 & \multirow{3}{*}{99.8} \\
\hline & & 4.98 & \\
\hline & & 4.99 & \\
\hline \multirow{3}{*}{ Tablet formulation } & \multirow{3}{*}{$5 \mathrm{mg}$} & 4.96 & \multirow{3}{*}{99.2} \\
\hline & & 4.98 & \\
\hline & & 4.97 & \\
\hline
\end{tabular}

Formula used for Calculation

$$
\begin{gathered}
\% \text { Relative standard deviation }=\frac{\text { Standard deviation of measurements }}{\text { mean of measurements }} \mathrm{X} 100 \\
\% \text { Recovery }=\frac{\text { Amount found }}{\text { Amount added }} \mathrm{X} 100 \\
\text { Amount found }=\frac{\text { Mean test absorbance }}{\text { Mean standard absorbance }} \mathrm{X} \text { standard concentration }
\end{gathered}
$$

Amount added $=$ weight / volume

\section{Calculation of limit for stability study:}

$$
\text { Limit }=\frac{\text { Absorbance of standard initial }- \text { absorbance of standard at time interval }}{\text { absorbance of standard initial }} \times 100
$$

\section{Summary \& Conclusion}

The quantitative estimation \& validation parameters of the pure drug and marketed tablet were compared. The quantitative estimation of pure drug and marketed tablet formulation was compared with the absorption maxima of the pure drug and marketed tablet formulation. Then calibration curve is plotted pure drug and marketed tablet formulation separately. Then for the assessment of various functional groups present in FTIR studies were performed. Various functional groups and peak were analyzed and compared with the standard which proved that the drug was Amlodipine. Also, the assay of the marketed tablet formulation was determined in which $99.2 \%$ of the drug was obtained and pure drug amlodipine $99.8 \%$. Then validation parameter was also determined according to USP 8 parameters like Accuracy, Precision, Specificity, Limit of detection, Limit of quantitation, Linearity, Ruggedness, and Robustness. These all parameters were studied between the pure drug and marketed tablet formulation. And resulting were the all validation parameter values similar to the marketed tablet formulation.

On the basis of the results obtained, it can be concluded that Quantitative method for estimation of drug in pure form and in commercially available marketed formulations is simple, accurate, precise, specific, selective, cost-effective, convenient, reproducible and reliable which meets the required acceptance criteria. This analytical method can be used for its intended purpose. For all the validation parameters, the values of standard deviation and $\%$ relative standard deviation were low which indicate higher degree of precision. This method can be successfully employed in future for routine estimation, quantification and quality control of pharmaceutical dosage forms. 


\section{References}

1. (2007) The Indian Pharmacopoeia commission, Indian Pharmacopoeia, Gaziabad, India, pp. 714.

2. Smith Alice E (1996) Validation \& verification protocol.

3. Vermesan Anea (1999) Validation \& Verification of knowledge band system. Computer Science, UK.

4. Thomas AB, Sheetal NJ, Shweta BD, Rabindra KN (2014) Estimation of Amlodipine Besylate and Telmisartan in Tablet Dosage Form. Pharm Tech 2(2): 1334-1341.

5. Nelson Mark (2010) Drug treatment of elevated blood pressure. Australian Prescriber 33(4): 108-112.

6. Sharma K, Agrawal SS, Gupta M (2012) Development and Validation of UV spectrophotometric method for the estimation of Curcumin in Bulk Drug and Pharmaceutical Dosage Forms. IJDDR 4(2): 375-380.

7. www.nlm.nih.gov/mesh/

8. Mishra P, Gupta Alka, Shah K (2007) Simultaneous estimation of atorvastatin calcium and amlodipine besylate from tablets. IPCS 69: 831-833.

9. Gidwani Bina, Vyas Amber (2014) UV-spectrophotometric method for estimation of altretamine in Bulk and pharmaceutical solid dosage form.

10. Thomas Asha B (2004) Simultaneous Spectrophotometric Estimation of Amlodipine Besylate and Telmisartan in Tablet Dosage Form. Der Pharma Chemica 4(2): 725-730.

11. Behera S, Ghanty S, Ahmad F, Santra S (2012) UV-Visible Spectrophotometric Method Development and Validation of Assay of Paracetamol Tablet Formulation. J Anal Boanal Techniques 3: 6-11.

12. ICH (2005) Validation of analytical procedures: text and methodology. ICH Guideline Q2 (R1), Switcherland.

13. ICH (1996) Stability testing of new drug substances and products. ICH, Q1A (R2), International Conference on Harmonization, Switcherland.

14. ICH (1996) Guidance for industry in; Q2B Validation on Analytical Procedures: Methodology. IF PMA, Switcherland.

15. Ludwig H (2007) Validation of Analytical Methods and Procedures. ICH, USA.

16. Sahu R, Patel VB (2006) Simultaneous spectrophotometric estimation of hydrochlorothiazide and bisoprolol fumarate in combined dosage forms. Indian J Pharma Sci pp. 764-767.

17. Jain HK, Agarwal RK (2000) Spectrophotometric method for simultaneous estimation of amlodipine besylate and lisinopril in tablets. Indian Drugs 37: 196-199.

18. Dahima R, Ashish P, Sanjay N (2010) Formulation and evaluation of mouth dissolving tablet containing amlodipine Besylate solid dispersion. Chem Tech 2(1): 706-715.

19. Jain Nilesh (2010) Spectrophotometric Method Development and Validation for Quantitative Estimation of Amlodipine Besylate in Bulk Drug and their Dosage Forms by Using Hydrotropic Agent. Eurasian J Anal Chem 5(3): 212-217.

20. Gajjar Anuradha K, Shah VD (2010) Simultaneous uvspectrophotometric Estimation of rosuvastatin and ezetimibe in their combined dosage forms. International Journal of Pharmacy and Pharmaceutical Sciences 2(1): 131-138.

21. Bernard Shyni (2011) Spectrophotometric method of estimation of Amlodipine besylate using hydrotropic solubilization. Journal of Applied Pharmaceutical Science 1(9): 177-180.
22. Kakde D, Jain D, Shrivastava V, Kakde R, Patil AV (2011) Cancer Therapeutics Oppor-tunities, Challenges and Advances in Drug Delivery. Journal of Applied Pharmaceutical Science 1(9): 1-10.

23. Singh E, Sharmak S, Pareek A, Dwivedi J, Yadav S, et al. (2011) Phytochemistry, traditional uses and cancer chemopreventive activity of Amla (Phyllanthus emblica): The Sustainer. Journal of Applied Pharmaceutical Science 2(1): 176-183.

24. Murthy Nandagudi Srinivasa, S Shalini, G Suman, Srekantaiah Pruthvish, Aleyamma Mathew (2009) Changing Trends in Incidence of Ovarian Cancer - the Indian Scenario. Asian Pac J Cancer Prev 10(6): 1025-1030.

25. (2014) Indian Pharmacopoeia Vol II. Published by the Controller of Publication, New Delhi, India, pp. 1045-1047.

26. Block JH, Beale JM (2004) Wilson and Grisvold's Textbook Organic Medicinal and Pharmaceutical Chemistry. Wolters Kluwer, London, UK, pp. 631.

27. Tripathi KD (2004) Essentials of Medical Pharmacology. (5 ${ }^{\text {th }}$ edn), Jaypee Brothers Medical Publishers, New Delhi, India, pp. 496.

28. Davidson AG (2002) Ultraviolet-visible absorption spectrophotometry. In: Beckett AH, et al. (Eds.), Practical Pharmaceutical chemistry, (4 ${ }^{\text {th }}$ edn), CBS Publishers and distributors, New Delhi, India, pp. 275-278.

29. Ghiorghis A, Talebian AH (1991) High-pressure liquid chromatography separation of potential impurities of Altretamine. Journal of Liquid Chromatography 14(12): 2331-2349.

30. Bernard Shyni (2014) UV - Spectrophotometric Estimation of Amlodipine Besylate by Using Hydrotropic Solubilization with $1 \mathrm{M}$ Sodium Acetate. Research Journal of Pharmaceutical, Biological and Chemical Sciences 5(4): 693-700.

31. (2009) British High Commission Landon. The British Pharmacopoeia, UK, pp. 5872-5877.

32. Santhosh MK, Sreedevi A, Kalyani L, Rao AL (2013) Development and validation of a stability indicating HPLC method for analysis of Altretamine in bulk drug and pharmaceutical formulations. Indian Journal of Research in Pharmacy and Biotechnology 1(6): 778-785.

33. Mandloi Dk, Tyagi PK, Rai VK, Dey S, Ashada RK, et al. (2009) Journal of Chemical and Pharmaceutical Research 1(1): 286-296.

34. Baghel US, Singhal M, Gupta MM, Singh HP, Shuchi D, et al. (2009) Journal of Chemical and Pharmaceutical Research 1(1): 271-275.

35. Helmut G, Alex W (2001) Hand Book of Analytical Techniques. ( $3^{\text {rd }}$ edn), Wiley Inter Science, New York, USA, pp. 283-326.

36. Chapman KG (1993) Validation terminology. In: Reddy IR, et al. (Eds), Pharmaceutical process validation, ( $\left.2^{\text {nd }} e d n\right)$, New York, USA, pp. $587-$ 596.

37. Jampana Praveen Kumar, Rajesh BH, Raveendra GB (2014) Visible spectroscopic method for estimation of Amlodipine besylate in tablets. IIPCBS 4(1): 173-177.

38. Bailey LC (2001) Chromatography. In: Gennaro AR (Eds.), The science and practice of pharmacy, $\left(20^{\text {th }}\right.$ edn), Remington, Lippincott Williams \& Wilkins, Philadelphia, USA, pp. 587-613.

39. Sanchaniya PM, Mehta FA, Uchadadiya NB (2013) Development and Validation of an RP-HPLC Method for Estimation of Chlorpheniramine Maleate, Ibuprofen, and Phenylephrine Hydrochloride in Combined Pharmaceutical Dosage Form. Chromatograph Research International 2013: 1-6.

40. Loni AB, Hosmani A, Gote A, Guled PA, Kumbhar ST (2013) Spectrophotometric Estimation of Tolterodine Tartarate in Bulk And Tablet Dosage Form. Am J PharmTech Res 3(6): 162-167. 
41. Beckett AH, Stenlake TB (1997) Practical pharmaceutical chemistry. ( $4^{\text {th }}$ edn), CBS Publisher and Distributor, New Delhi, India, pp. 277-280.

42. Masih Manisha, Abhilasha M, Nandy BC (2014) Spectrophotometric simultaneous estimation of amlodipine besylate and losartan potassium in tablet dosage forms. Asian Journal of Pharmaceutical and Clinical Research 7(4): 61-63.

43. Vora DN, Kadav AA (2008) Development and validation of a simultaneous HPLC method for estimation of bisoprolol fumarate and amlodipine besylate from tablets. Indian J Pharm Sci 70(4): 542-546.

44. Chitlange SS, Imran M, Sakarkar DM (2008) RP HPLC method for simultaneous estimation of amlodipine and metoprolol in tablet formulation. Asian J Pharm Sci 2: 232-234.

45. Che-Ming Jack Hu, Santosh Aryal, Liangfang Zhang (2010) Nanoparticle-assisted combination therapies for effective cancer treatment. Ther Deliv 1(2): 323-334.

46. Clande Jean (2005) CADP protocol validation and verify-cation toolbox.

47. Masih Abhilasha (2012) Simultaneous spectrophotometric estimation of amlodipine besylate and telmisartan in tablet dosage form.
48. Patil VP, Devdha SJ, Angadi SS, Shelke SD, Jadhav VR, et al. (2013) New Ecofriendly Validated Spectrophotometric Method for the Estimation of Amlodipine Besylate in Bulk Drug Using Ninhydrin. Asian Journal of Biomedical and Pharmaceutical Sciences.

49. Pradhan Kishanta Kumar (2011) Method Development, Validation and Stability Study of Irbesartan in Bulk and Pharmaceutical Dosage Form by UV-Spectrophotometric Method. International Journal of Pharmaceutical \& Biological Archive 2(4).

50. Madan Mohan RM, Jyothirmai K, Mahidhar R, Rambabu P, Anka RE, et al. (1996) A Novel Review on Anti-Hypertensive Drug CombinationAtenolol and Amlodipine. International Journal of Pharmaceutical and Chemical Sciences 2(2): 1086-1089.

51. Law M, Wald N, Morris J (2003) Lowering blood pressure to prevent myocardial infarction and stroke: a new preventive strategy. Health Technol Assess 7(31): 1-94.

52. Nelson MR, McNeil JJ, Peeters A, Reid CM, Krum H (2001). PBS/RPBS cost implications of trends and guideline recommendations in the pharmacological management of hypertension in Australia, 19941998. Med J Aust 174(11): 565-568. 